Reprod. Nutr. Dévelop., 1987, 27 (5), 907-919.

\title{
Effects of phosphorus deficiency on rumen microbial activity associated with the solid and liquid phases of a fermentor (Rusitec)
}

\author{
Sylvie KOMISARCZUK, Michelle DURAND, Ph. BEAUMATIN, \\ Geneviève HANNEQUART
}

Station de Recherches de Nutrition, I.N.R.A., 78350 Jouy-en-Josas, France.

Summary. The rumen simulation technique (Rusitec) has been used to study the effects of phosphorus (P) deficiency on bacterial protein synthesis and chemical composition and on adenosine triphosphate (ATP) concentrations in the solid and liquid phases of fermentors. $16 \mathrm{~g}$ DM of a P-deficient mixed diet was put into each vessel daily and the vessels were infused with about $1 \mathrm{I}$ of a $\mathrm{P}$-deficient $(0 \mathrm{mg}$ of $P)$ or P-supplemented $(120 \mathrm{mg}$ of $P / I)$ buffer. Two vessels per treatment were used, and during a second experimental period the deficient and supplemented buffers were interchanged to determine the effects of $P$ repletion and depletion.

The proportion of bacterial $\mathrm{N}$ directly incorporated from dietary amino acids or peptides was greater in solid-associated bacteria (SAB) than in liquid-associated bacteria (LAB) (46 vs $19 \%$ ). P deficiency increased this proportion in both bacterial populations. Protein synthesis associated with the solid phase represented about $30 \%$ of the total protein synthesis in the system. $P$ deficiency induced a marked decrease in microbial protein synthesis in both phases. Microbial yield declined by about 5 points $(\mathrm{g} \mathrm{of} \mathrm{N} / \mathrm{kg}$ OMF) in P-deficient conditions. ATP concentrations were greatly reduced in both phases but $P$ deficiency had no effect on protozoal numbers.

The effects of $P$ depletion during period II were similar to those of $P$ deficiency in period $I$, and $P$ repletion showed that the effects of $P$ deficiency were almost entirely reversible.

\section{Introduction.}

Moderate phosphorus (P) deficiency is widespread, particularly in grazing areas of tropical countries (Smith, 1984) or when diets high in low P-containing by-products (pulp, molasses, treated straw) are fed. Since low $P$ intake is often shown to reduce the amount of salivary $P$ entering the rumen, and as a consequence the soluble $P$ concentration in the rumen (Durand et al., 1982), rumen function may be impaired. In vivo studies on the effect of $P$ deficiency on rumen microbial digestion and protein synthesis have not always shown clear-cut results because of large variations in the responses of the hosts in terms of food 
intake and endogenous $P$ return (Witt and Owens, 1983 ; Milton and Ternouth, 1985). However, some authors using semi-purified diets have pointed out the clear-cut effect of reduced $P$ intake on the degradative capacities of rumen microbes (Farries and Krasnodebska, 1972; Durand et al., 1983), urea $N$ utilization (Durand et al., 1983 ; Höller, Breves and Martens, 1983) and microbial $\mathrm{N}$ turnover (Lessmann, Breves and Höller, 1985 ; Breves, Höller and Lessman, 1985).

Recently, a range of inorganic phosphorus concentrations was experimented (Komisarczuk, Merry and McAllan, 1987) using a continuous culture rumen stimulation technique developed by Hoover, Crooker and Sniffen (1976), modified by Merry, Smith and McAllan (1987). In terms of $P$ requirements of the rumen microbial population, results showed a different requirement for fibre digestion than for protein synthesis. Adenosine triphosphate (ATP) concentrations and cellulose digestion were the most affected by $P$ depletion. However, this technique involving a continuous food supply optimized fermentation compared to in vivo conditions. Furthermore, the microbial biomass of each solid and liquid phase was not differentiated. Another type of continuous culture system, the rumen stimulation technique (Rusitec), designed by Czerkawski and Breckenridge (1977), allows a longer retention time of the solid material and could reproduce better in vivo digestion characteristics. Also, with this system the solid and liquid phases could be easily separated.

In the present work, the Rusitec was used to determine the role of $P$ on microbial activity associated with the two main compartments of the rumen. The composition of the low-P diet used as a substrate was similar to that used by Komisarczuk, Merry and McAllan (1987). Data concerning the digestive parameters (organic matter and cell wall degradation, volatile fatty acids and gas production) have been published elsewhere (Komisarczuk et al., 1986). The results reported here deal with the effects of $P$ deficiency on bacterial chemical composition, growth and ATP concentration.

\section{Material and methods.}

Inoculum source. - Six " lle-de-France " wethers weighing 50 to $60 \mathrm{~kg}$ and fitted with permanent rumen cannulae, were used as donors. They were fed a pelleted diet of chopped barley straw (0.477), sugar beet pulp (0.284), tapioca (0.195), urea (0.032) and a mineral and vitamin mixture (0.012). The latter supplied the following amounts per $\mathrm{kg}$ of air-dried feed : $\mathrm{P}, 2.35 \mathrm{~g} ; \mathrm{Mg}, 0.42 \mathrm{~g} ; \mathrm{Zn}, 68 \mathrm{mg}$; $\mathrm{Mn}, 60 \mathrm{mg}$; $\mathrm{Cu}, 0.9 \mathrm{mg}$; Co, $0.9 \mathrm{mg} ; \mathrm{l}, 0.7 \mathrm{mg}$; Se, $0.16 \mathrm{mg}$; vitamin A, $180 \mathrm{IU}$; vitamin $\mathrm{D}_{3}, 6 \mathrm{IU}$; vitamin $\mathrm{E}, 0.6 \mathrm{IU}$; thiamin chlorhydrate, $0.14 \mathrm{mg}$. The diet was given at a level of $1.1 \mathrm{~kg}$ of air-dried feed/day in two equal portions at 09.00 and $17.00 \mathrm{~h}$ and supplied $23.8 \mathrm{~g}$ of $\mathrm{N}, 3.52 \mathrm{~g}$ of $\mathrm{P}$ and $9.4 \mathrm{MJ}$ of metabolizable energy/day, which was sufficient for maintenance requirements.

Samples of rumen contents (about $1 \mathrm{l}$ /animal) were taken by gentle suction about $2 \mathrm{~h}$ after the morning meal. They were pooled and strained through four layers of surgical gauze. 
Continuous culture apparatus and its operation. - The semi-continuous culture system built in our workshop was adapted from Czerkawski and Breckenridge (1977). Four 1 /liter vessels (V1, V2, V3, V4) were used. The general procedure for starting and running the system has been described by Czerkawski (1984). The experiment was started by placing $80 \mathrm{~g}$ of solid digesta in one nylon bag, a solid pelleted feed $(16 \mathrm{~g} \mathrm{DM})$ in a second bag, and then filling the reaction vessel with $500 \mathrm{ml}$ of strained rumen liquid containing about $500 \mathrm{mg}$ of Pi/l. The volume of the fermentors was adjusted to 1 liter with buffer. After $24 \mathrm{~h}$, the solid inoculum was removed and a new food bag was placed in the vessel. Subsequently, the older bag was removed every day and a new one was placed in the vessel so that each bag remained 2 days in the vessel. The nylon bags used (size : $160 \times$ $80 \mathrm{~mm})$ were made from a fine material $\left.!^{*}\right)(150-\mu \mathrm{m}$ pore size). The pelleted feed was P-deficient $(1.17 \mathrm{~g}$ of $\mathrm{P} / \mathrm{kg} \mathrm{DM})$ and contained barley straw $(0.50)$, sugar beet pulp (0.29) and tapioca (0.21). Table 1 gives the chemical analysis of the diet and the daily input of its main elements in one nylon bag. Liquid turnover rate was determined by continuous infusion of a buffer at a rate of $1 \mathrm{l} /$ day/vessel. Therefore, one bag of feed corresponded to about 1 liter of liquid effluent.

TABLE 1

Chemical composition and daily input of the experimental diet.

\begin{tabular}{lcc}
\hline & $\begin{array}{r}\text { Chemical composition } \\
(\mathbf{g} / \mathbf{k g})\end{array}$ & $\begin{array}{c}\text { Daily input } \\
(\mathbf{g} / \mathbf{b a g})\end{array}$ \\
\hline Dry matter & 924.00 & 16.17 \\
Organic matter & 865.00 & 15.15 \\
Phosphorus & 1.17 & 0.018 \\
Total nitrogen & 9.10 & 0.15 \\
Hemicellulose (NDF-ADF) & 242.00 & 3.62 \\
Cellulose (ADF-lignin) & 303.00 & 4.53 \\
Lignin & 41.53 & 0.62 \\
\hline
\end{tabular}

Experimental procedure. - The study was divided into two periods. During the first one (I), V1 and V2 were infused with the control buffer contained $120 \mathrm{mg}$ of $\mathrm{P} / \mathrm{I}$ and $\mathrm{V} 3$ and $\mathrm{V} 4$ with the P-deficient buffer. The compositions of these two solutions are given in table 2 . In the P-deficient buffer the phosphate removed was replaced by sodium carbonate and sodium chloride to maintain the same buffering capacity and osmolarity. Six days were allowed for equilibration and 11 for sampling. The second period (II) started on Day 17 ; the control and Pdeficient buffers were interchanged so that the previously P-deficient vessels (V3 and V4) were the P-repleted ones and the control vessels (V1 and V2) the Pdepleted ones. Samples were taken after a new equilibration period of 4 days, judged sufficient from the volatile fatty acid (VFA) production which stabilized.

$\left({ }^{*}\right)$ Tripette et Renaud, 39, rue J.-J. Rousseau, 75038 Paris Cedex 01. 
TABLE 2

Chemical composition $(\mathrm{g} / \mathrm{l})$ of the buffers infused into the vessels.

\begin{tabular}{lcc}
\hline \multicolumn{1}{c}{ Chemicals } & P-supplemented buffer & P-deficient buffer \\
\hline $\mathrm{NaHCO}_{3}$ & 7.56 & 7.81 \\
$\mathrm{Na}_{2} \mathrm{HPO}_{4}, 12 \mathrm{H}_{2} \mathrm{O}$ & 1.38 & - \\
$\mathrm{NaCl}$ & 0.45 & 0.66 \\
$\mathrm{KCl}$ & 0.35 & 0.35 \\
$\mathrm{MgCl}$ & 0.077 & 0.077 \\
Thiamin & 0.0002 & 0.0002 \\
\hline
\end{tabular}

The VFA were determined on the daily effluent in each vessel between Days 11 and 28. Ammonia in the effluent and microbial $\mathrm{N}$ were determined in both the liquid and solid phases on Days 12, 15 and 17 (period I) and Days 24 and 27 (period II). Bacteria from both the effluents and bag residues were harvested on Days 9 and 16 (period I) and on Day 25 (period II). ATP and the number of protozoa in the fermentors and bag residues were determined on Days 12, 15 and 17 (period I) and on Days 24 and 27 (period II).

Analytical procedure. - The VFA were analysed in the liquid effluent by gas chromatography according to Ottenstein and Bartley (1971).

ATP concentrations were measured in the liquid phase of the vessels four times a day (just before and 2, 4 and $6 \mathrm{~h}$ after the feed bag was changed) and in the washed solid residues, as described by Komisarczuk, Durand and Hannequart (1984). One $\mathrm{ml}$ of liquid or $1 \mathrm{~g}$ of solid was treated with $9 \mathrm{ml}$ of dimethylsulfoxide for ATP extraction and ATP was determined by bioluminescence.

Protozoa were counted using a Fuchs-Rosenthal cell after fixation in a $10 \%$ (V/V) formaldehyde solution in $\mathrm{NaCl} 9 \%$ (W/V).

Ammonia nitrogen $\left(\mathrm{NH}_{3}-\mathrm{N}\right)$ was estimated after trichloracetic precipitation using an automated method (Michel, 1971).

Protein synthesis was estimated using the ${ }^{15} \mathrm{~N}$ labelling technique. Urea- ${ }^{15} \mathrm{~N}$ was continuously infused with the buffer ( $800 \mathrm{mg} / \mathrm{l}$ ), supplying $373 \mathrm{mg}$ of $\mathrm{N} / \mathrm{l}$ with a ${ }^{15} \mathrm{~N}$ enrichment of 1.23 (atom \% excess).

Bacteria from the liquid effluent were harvested using a differential centrifugation technique (McAllan and Smith, 1974). Those associated to the washed solid residues were first removed by mechanical pummelling, referred to as " stomaching " by Merry and McAllan (1983). The sample was mixed thoroughly in a solution of saline $(5 \mathrm{mg} / \mathrm{g})$, placed in a thick polyethylene bag and subjected to mechanical pummelling between two metal plates for $5 \mathrm{~min}$ in a stomacher apparatus (Stomacher, Lab. Blender 400, A.J. Seward \& Co. Ltd., London). It was then filtered and the residue subjected again to the same treatment. Bacteria from the pooled filtrates were separated by differential centrifugation.

The pellets resulting from the centrifugation $(30000 \times \mathrm{g}$ for $15 \mathrm{~min})$ of total liquid effluent $(25 \mathrm{ml})$ and solid residue $(5 \mathrm{~g})$ were washed twice with a saline solution and once with distilled water. Total nitrogen (N) was determined by the Kjeldahl method on both the washed pellets and harvested bacteria from each 
phase. After total $\mathrm{N}$ determination, neutralized samples containing distilled $\mathrm{NH}_{3}$ in the form of $\left(\mathrm{NH}_{4}\right)_{2} \mathrm{SO}_{4}$ were acidified with $\mathrm{H}_{2} \mathrm{SO}_{4}$ and evaporated until dryness. $\mathrm{N}_{2}$ was released by hypobromite under vacuum for mass spectrometry analysis of ${ }^{15} \mathrm{~N}$.

${ }^{15} \mathrm{~N}$ enrichment in the ammonia pool of the liquid phase was estimated by the same procedure after $\mathrm{NH}_{3}$ distillation in the presence of magnesium oxide. ${ }^{15} \mathrm{~N}$ enrichments were determined at the INRA "Station agronomique de Laon ", France.

The total phosphorus in harvested bacteria was determined using the Bartlett method (1959). The organic matter content of harvested bacteria was determined by drying at $80^{\circ} \mathrm{C}$ until constant weight was obtained.

Calculations. - The amounts of organic matter fermented (OMF) were calculated from the molar output of each VFA using the Van Nevel and Demeyer formula (1977) :

$$
\left.\frac{\text { (Ac. }}{2}+\frac{\text { Pro. }}{2}+\text { But. }+ \text { Val. }\right) \times 162
$$

The proportion of microbial $\mathrm{N}$ in total $\mathrm{N}$ was obtained by the ratio of the ${ }^{15} \mathrm{~N}$ specific enrichment (atom \% excess) of the sample to ${ }^{15} \mathrm{~N}$ specific enrichment (atom \% excess) of the isolated bacteria from the same phase.

The proportion of bacterial $\mathrm{N}$ derived from ammonia was calculated as the ratio of the ${ }^{15} \mathrm{~N}$ specific enrichment of the isolated bacteria to the ${ }^{15} \mathrm{~N}$ specific enrichment of the $\mathrm{NH}_{3}$ pool in the liquid effluent.

Statistical analysis. - The daily means of two vessels in each treatment and period were compared using the paired t-test (Snedecor and Cochran, 1972) (i. e. $n=6: 2$ vessels, 3 sampling days and $n=4: 2$ vessels, 2 sampling days).

\section{Results.}

Period I.

Chemical composition of bacteria and ammonia incorporation. - In the control vessels, differences in $\mathrm{N}$ content and ammonia- $\mathrm{N}$ incorporation were observed between the liquid-associated bacteria $(L A B)$ and the solid-associated bacteria (SAB) (table 3). Nitrogen content and its ${ }^{15} \mathrm{~N}$ enrichment were significantly lower $(\mathrm{P}<0.001)$ in SAB than in LAB. As a consequence, the proportion of bacterial $\mathrm{N}$, derived from $\mathrm{N}$ compounds more complex than $\mathrm{NH}_{3}$ (dietary amino acids and peptides), was greater in SAB than in LAB (46 vs $19 \%$ ).

$P$ deficiency had some effects on bacterial chemical composition (table 3 ). The $N$ content of $L A B$ was significantly lower $(P<0.01)$ and $15 \mathrm{~N}$ specific enrichment was reduced in both microbial populations ( $S A B$ and $L A B$ ) by the lack of $P$.

Microbial $N$ production. yield and proteolytic activity. - In the solid phase, protein synthesis represented about $30 \%$ of total microbial $\mathrm{N}$ production. $\mathrm{P}$ deficiency induced a marked decrease in microbial protein synthesis in both phases 
TABLE 3

Chemical composition and ${ }^{15} \mathrm{~N}$ specific enrichment (atom \% excess) of liquid (LAB) and solid (SAB)-associated bacteria (mean \pm SEM).

\begin{tabular}{|c|c|c|c|c|c|c|}
\hline \multirow{2}{*}{$\begin{array}{ll} & \text { Period } \\
\text { Vessels } & \end{array}$} & \multicolumn{4}{|c|}{ I } & \multicolumn{2}{|c|}{ II } \\
\hline & & $1-2$ & & $3-4$ & $1-2$ & $3-4$ \\
\hline \multirow[t]{2}{*}{ Buffer $P$ input $(\mathrm{mg} / \mathrm{d})$} & & 120 & & 0 & 0 & 120 \\
\hline & \multicolumn{4}{|c|}{$n=4$} & \multicolumn{2}{|c|}{$n=2$} \\
\hline \multicolumn{7}{|l|}{$\mathrm{LAB}$} \\
\hline \multirow{2}{*}{$\begin{array}{l}\text { Organic matter } \\
\text { (\% dry matter) } \\
\mathrm{N}(\% \mathrm{DM}) \\
\mathrm{P}(\% \mathrm{DM}) \\
\mathrm{N} / \mathrm{P} \\
15_{\mathrm{N}} / 14_{\mathrm{N}} \\
\text { Proportion of bacterial } \\
\mathrm{N} \text { incorporated from } \\
\mathrm{NH}_{3}-\mathrm{N}(\%)\end{array}$} & $\begin{array}{l}83.3 \\
8.03 \\
1.17 \\
7.0 \\
0.929\end{array}$ & $\begin{array}{l} \pm 1.0^{\mathrm{a}} \\
\pm 0.20^{\mathrm{a}} \\
\pm 0.10^{\mathrm{a}} \\
\pm 0.4^{\mathrm{a}} \\
\pm 0.009^{\mathrm{a}}\end{array}$ & $\begin{array}{l}78.7 \\
6.94 \\
0.99 \\
7.1 \\
0.866\end{array}$ & $\begin{array}{l} \pm 3.7^{\mathrm{a}} \\
\pm 0.20^{\mathrm{b}} \\
\pm 0.10^{\mathrm{a}} \\
\pm 0.3^{\mathrm{a}} \\
\pm 0.005^{\mathrm{b}}\end{array}$ & $\begin{array}{l}81.8 \\
7.89 \\
1.07 \\
7.4 \\
0.880\end{array}$ & $\begin{array}{l}74.6 \\
7.62 \\
0.98 \\
7.8 \\
0.961\end{array}$ \\
\hline & 0.81 & $\pm 0.01^{a}$ & 0.76 & $\pm 0.01^{b}$ & 0.76 & 0.81 \\
\hline \multicolumn{7}{|l|}{ SAB } \\
\hline $\begin{array}{l}N(\% D M) \\
P(\% D M) \\
N / P \\
15_{N} / 14_{N} \\
\text { Proportion of bacterial }\end{array}$ & $\begin{array}{l}6.80 \\
0.93 \\
7.10 \\
0.611\end{array}$ & $\begin{array}{l} \pm 0.10^{\mathrm{a}} \\
\pm 0.13^{\mathrm{a}} \\
\pm 1.0^{\mathrm{a}} \\
\pm 0.014^{\mathrm{a}}\end{array}$ & $\begin{array}{l}6.80 \\
1.10 \\
6.70 \\
0.534\end{array}$ & $\begin{array}{l} \pm 0.2^{\mathrm{a}} \\
\pm 0.23^{\mathrm{a}} \\
\pm 1.4^{\mathrm{a}} \\
\pm 0.017^{\mathrm{b}}\end{array}$ & $\begin{array}{c}7.20 \\
0.63 \\
11.4 \\
0.477\end{array}$ & $\begin{array}{c}7.20 \\
0.74 \\
10.0 \\
0.566\end{array}$ \\
\hline $\begin{array}{l}\mathrm{N} \text { incorporated from } \\
\mathrm{NH}_{3}-\mathrm{N}(\%)\end{array}$ & 0.54 & $\pm 0.01^{a}$ & 0.47 & $\pm 0.01^{b}$ & 0.41 & 0.50 \\
\hline
\end{tabular}

$a \neq b: p<0.05$

TABLE 4

Ammonia $\mathrm{N}\left(\mathrm{NH}_{3}-\mathrm{N}\right)$ production, specific ${ }^{15} \mathrm{~N}$ enrichment (atom \% excess) of the ammonia pool, microbial $N$ production and microbial $N$ yield.

Mean values with pooled standard errors of the means (SEM).

\begin{tabular}{|c|c|c|c|c|c|}
\hline \multirow{2}{*}{$\begin{array}{ll} & \text { Period } \\
\text { Vessels }\end{array}$} & \multicolumn{2}{|c|}{1} & \multicolumn{2}{|c|}{ II } & \multirow[t]{2}{*}{ SEM } \\
\hline & $1-2$ & $3-4$ & $1-2$ & $3-4$ & \\
\hline \multirow[t]{2}{*}{ Buffer $P$ input $(\mathrm{mg} / \mathrm{d})$} & 120 & 0 & 0 & 120 & \\
\hline & \multicolumn{2}{|c|}{$n=6$} & \multicolumn{2}{|c|}{$n=4$} & \\
\hline $\begin{array}{l}\mathrm{NH}_{3}-\mathrm{N} \text { in liquid effluent }(\mathrm{mg} / \mathrm{d}) \\
15 \mathrm{~N} /{ }^{14} \mathrm{~N} \text { in } \mathrm{NH}_{3}-\mathrm{N} \text { pool } \\
\text { Microbial } \mathrm{N} \text { production (mg/d) }\end{array}$ & $\begin{array}{r}308^{\mathrm{a}} \\
1.142^{\mathrm{a}}\end{array}$ & $\begin{array}{r}339^{\mathrm{b}} \\
1.147^{\mathrm{a}}\end{array}$ & $\begin{array}{r}327^{\mathrm{b}} \\
1.155^{\mathrm{b}}\end{array}$ & $\begin{array}{r}299^{a} \\
1.147^{\mathrm{a}}\end{array}$ & $\begin{array}{l}8.21 \\
0.003\end{array}$ \\
\hline $\begin{array}{l}\text { Liquid phase } \\
\text { Solid phase } \\
\text { Total }\end{array}$ & $\begin{array}{r}103^{\mathrm{a}} \\
47^{\mathrm{a}} \\
150^{\mathrm{a}}\end{array}$ & $\begin{array}{l}64^{\mathrm{b}} \\
34^{\mathrm{b}} \\
98^{\mathrm{b}}\end{array}$ & $\begin{array}{c}64^{\mathrm{b}} \\
45^{\mathrm{ab}} \\
109^{\mathrm{b}}\end{array}$ & $\begin{array}{r}86^{\mathrm{b}} \\
58^{\mathrm{a}} \\
144^{\mathrm{a}}\end{array}$ & $\begin{array}{l}4.26 \\
2.99 \\
5.83\end{array}$ \\
\hline $\begin{array}{l}\text { Organic matter fermented }(*) \\
(\mathrm{n}=12) \mathrm{g} / \mathrm{d} \\
\text { Microbial } \mathrm{N} \text { yield }(\mathrm{g} \mathrm{N} / \mathrm{kg} \text { OMF) }\end{array}$ & $\begin{array}{r}6.2^{\mathrm{a}} \\
24.0^{\mathrm{a}}\end{array}$ & $\begin{array}{r}4.8^{\mathrm{b}} \\
20.7^{\mathrm{b}}\end{array}$ & $\begin{array}{r}5.0^{\mathrm{b}} \\
21.1^{\mathrm{b}}\end{array}$ & $\begin{array}{c}6.1^{\mathrm{a}} \\
24.1^{\mathrm{ab}}\end{array}$ & $\begin{array}{l}0.1 \\
0.55\end{array}$ \\
\hline
\end{tabular}

$a \neq b \neq c ; p<0.05$.

$(*)$ Calculated from VFA production according to Van Nevel and Demeyer (1977): $\mathrm{OMF}=\left(\frac{A_{c}+\text { Pro }}{2}+\right.$ But + Val $) \times 162$. 
(table 4) but the effect was more pronounced in the liquid phase. Overall microbial production was more intensely reduced by the lack of $P$ than the organic matter fermented $(-35 v s-22 \%)$. As a result, the microbial efficiency of protein synthesis was significantly decreased (by $5 \mathrm{~g}$ of N/kg OMF) in P-deficient vessels. The $\mathrm{NH}_{3}-\mathrm{N}$ production in P-deficient vessels was increased by about $30 \mathrm{mg} /$ day compared to control vessels.

However, it can be calculated that $P$ deficiency had little effect on proteolysis in the system. In control vessels the proportion of $\mathrm{NH}_{3}-\mathrm{N}$ of dietary origin ranged around $8 \%$ of the total $\mathrm{NH}_{3}-\mathrm{N}$. Adding the total microbial $\mathrm{N}$ derived from dietary $\mathrm{N}$, it can be calculated that protein degradation was about $43 \%$. In P-deficient vessels the proportion of deaminated dietary protein or free amino acids was only reduced by about $14 \%$. Ureolytic activity was not affected since no urea was found in the liquid effluent, whatever the amount of $P$ put into the system.

ATP production and protozoal number. - Measurement of ATP concentrations at different times of the day in the liquid content of the vessels showed that a fresh feed input induced a significant increase in ATP concentration, whatever the P supply (fig. 1). However, in P-deficient vessels ATP concentrations were markedly reduced and the effect was particularly clear $24 \mathrm{~h}$ after the feed bag was changed (table 5 ).

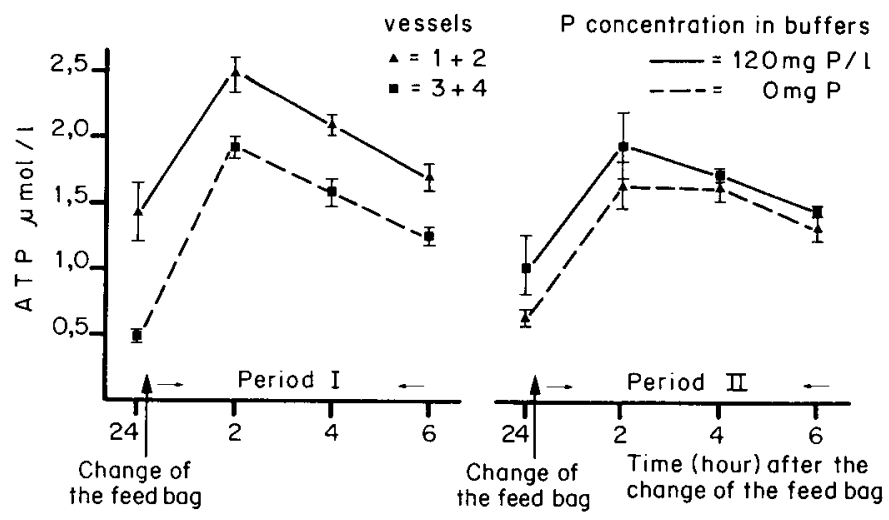

FIG. 1. - Profile of ATP concentrations in the liquid phase during both experimental periods.

The comparison of ATP in liquid phase and washed solid residues $24 \mathrm{~h}$ after the bag had been changed showed that the amount of ATP in the latter represented only about $10 \%$ of the total, whereas $30 \%$ of the microbial population was found to be associated with the washed solid residues (table 5).

The decrease in the number of protozoa in liquid and solid phases in P. deficient vessels was not significant (table 5). The number of them associated with the solid phase represented only about $5 \%$ of the total, but they were also counted on washed residues. 
TABLE 5

ATP and protozoal number in liquid and solid phases of vessels.

Mean values with pooled standard errors of the means (SEM).

\begin{tabular}{|c|c|c|c|c|c|}
\hline Period & \multicolumn{2}{|c|}{1} & \multicolumn{2}{|c|}{ II } & SEM \\
\hline Vessels & $1-2$ & $3-4$ & $1-2$ & $3-4$ & \\
\hline \multirow[t]{2}{*}{ Buffer $P$ input $(\mathrm{mg} / \mathrm{d})$} & 120 & 0 & 0 & 120 & \\
\hline & \multicolumn{2}{|c|}{$n=6$} & \multicolumn{2}{|c|}{$n=4$} & \\
\hline
\end{tabular}

ATP in vessels $(*)$

Liquid phase $(* *)$

(nmol/vessel)

Solid phase $(* * *)$

$1440^{\mathrm{a}}$

$490^{\mathrm{b}}$

$640^{c}$

$1030^{\text {ac }}$

120

(nmol/bag)

$160^{\mathrm{a}}$

$56^{\mathrm{b}}$

$63^{b}$

$140^{\mathrm{a}}$

14

Protozoal number

Liquid phase $\left({ }^{* *}\right)$

( $\times 105 /$ vessel)

Solid phase $(* * *)$

( $\times 10^{5} / \mathrm{bag}$ )

$61^{a}$

$49^{a}$

$54^{\mathrm{a}}$

$68^{a}$

4

$3.4^{\mathrm{a}}$

$2.2^{\mathrm{a}}$

$3.6^{a}$

$3.7^{a}$

0.3

$a \neq b \neq c: p<0.05$. phase.

(*) Concentrations expressed per vessel are about equivalent to the amount per liter for the liquid

$(* *)$ Just before the change of the bag.

$(* * *)$ After $48 \mathrm{~h}$ of incubation.

\section{Period //}

Phosphorus depletion. - During the second experimental period, removal of $P$ from the buffer solution of previous control vessels mainly led to the same results as in period I, i. e. reduction of microbial $\mathrm{N}$ of $\mathrm{NH}_{3}-\mathrm{N}$ origin in both $\mathrm{SAB}$ and LAB, a decline in microbial production and microbial $N$ yield. The chemical composition of bacteria and the number of protozoa were not affected. $P$ deficiency had no effect on ureolysis and proteolysis as during the first period.

Concerning ATP concentrations, this period was rather different from the first. $P$ depletion did not induce such a marked decrease in ATP concentration ; at least the effect was not significant in the liquid phase. In the solid phase the reduction of ATP content per bag was almost as great as in the first period.

Phosphorus repletion. - For most of the parameters measured, P repletion led to a good recovery of the values found during period $I$ in control vessels. The major difference concerned ATP concentrations in the liquid phase of the fermentors which were significantly lower at all times of the day in vessels V 3 and V4 than in control vessels during the first period. These low ATP concentrations partially explain the non-significant differences found during period II between $P$ repleted and $\mathrm{P}$-depleted vessels. 


\section{Discussion.}

Characteristics of the control vessels. - One of the main advantages of the RUSITEC is that the microbial population associated with the liquid and solid phases of the rumen can be studied separately. However, in order to keep the system stable, all washings from the removed bags must be returned to the vessels. These washings contain loosely-attached microorganisms which constitute compartment 2 of the system (Czerkawski, 1984). If these microorganisms return inside the bag, they cannot be quantified. Our results here essentially concern compartment 1 (free suspension of microorganisms) and compartment 3 (microorganisms closely attached to the solid phase). This might explain some discrepancies with other authors quoted by Merry and McAllan (1983) who found the majority of rumen bacteria associated with the solid phase.

The use of $15 \mathrm{~N}$-labelling confirmed previous observations showing that part of the bacterial $\mathrm{N}$ can be directly derived from dietary protein or other non-urea sources (McMeniman, Ben Ghedalia and Elliott, 1976; Salter, Daneshvar and Smith, 1979). Since amino acid incorporation was greater in SAB than in LAB, our results support the observations of these authors showing that the level of bacterial amino acid directly incorporated is related to the amount of protein available in situ.

These differences in ${ }^{15} \mathrm{~N}$ specific enrichment of $S A B$ and LAB emphasize the necessity of a differential study of these two bacterial populations in order to obtain a reliable estimate of total microbial protein synthesis. ${ }^{15} \mathrm{~N}$ specific enrichment of liquid-associated bacteria alone could result in an underestimation of total microbial protein synthesis by at least $10 \%$. This problem must also be taken into account when RNA is used as a microbial marker since Merry and McAllan (1983) and Bates et al. (1985) have observed differences between LAB and $\mathrm{SAB}$ in terms of RNA/N ratio. Other differences in the chemical composition between the two bacterial populations observed in this experiment (ash, N, P) are in agreement with previous findings (Czerkawski, 1976; Merry and McAllan, 1983).

The microbial yield obtained in the control vessels was rather low $(20$ to $25 \mathrm{~g}$ of $\mathrm{N} / \mathrm{kg}$ OMF) compared to the average in vivo values ( 30 to $35 \mathrm{~g}$ of N/kg OMF) recently reported by Demeyer and Van Nevel (1986) and to that obtained using the continuous culture system with the same diet (Komisarczuk, Merry and McAllan, 1987). A low yield was already observed by Durand et al. (1986a) using the Rusitec. This could be explained by the long retention time of the solid phase but, as part of the microbial population of compartment 2 may not be taken into account, the yield could be underestimated.

The distribution of ATP concentrations between liquid and particulate material was easy to study using the Rusitec apparatus. ATP associated with the washed residues represented only $10 \%$ of the total. This value is much lower than in vivo findings. In the rumen contents of cows fed a ration of hay and cereals, Forsberg and Lam (1977) found between 20 and $70 \%$ of the ATP associated with the solid particulate material. After 48 -hour retention in the bag, 
SAB could be expected to be in a late growth phase contrary to $L A B$ for which retention time was lower ( 24 vs $48 \mathrm{~h}$ ). It is well known that ATP concentrations change with the growth stage (Forrest, 1965 ; Forsberg and Lam, 1977 ; Nuzback et al., 1983). In addition, it is probable that washing the bag removed part of the ATP from the solid residues since recent observations with straw (unpublished data) show that the ATP contained in compartment 2 equals that of the washed solid residue. The increase in ATP concentrations $2 \mathrm{~h}$ after the renewal of the feed bag shows variations in the rate of fermentation as it occurs in vivo after a meal but, in this system, it could be partly due to the return of compartment 2 to the vessels. Nevertheless, Rusitec may be closer to normal animal feeding conditions than a true continuous culture system. Furthermore, our results in period II show that the system is able to maintain fermentation for about 3 weeks without important changes in the equilibrium of the microbial population.

Consequences of phosphorus deficiency. - $\mathrm{P}$ deficiency reduced overall protein synthesis by $45 \%$, which confirms results obtained in vivo by Breves and Höller (1985) and Lessmann, Breves and Höller (1985) and in vitro by Bonilla (1976) and Komisarczuk, Merry and McAllan (1987). In the P-deficient medium, the $P$ supply was solely of dietary origin. It is likely that this form of $P$ was preferentially used by $S A B$, as microbial production associated with the solid residues was less affected than that of the liquid phase. It is relevant to mention that cellulolysis which depends mainly on $S A B$ activity was much affected by $P$ deficiency $(-55 \%)$ in the same experiment (Komisarczuck et al., 1986). This fact confirms that cellulose digestion is more affected by a lack of $P$ than protein synthesis itself, as already observed (Komizarczuk, Merry and McAllan, 1987).

It is of interest to note that $\mathrm{P}$ deficiency had a significant effect on $\mathrm{NH}_{3}$ utilization by bacteria associated to both the liquid and the solid phases. The role of $\mathbf{P}$ in nitrogen-ammonia assimilation by rumen bacteria needs further investigation.

The reduction of microbial $N$ yield in P-deficient vessels has already been observed by Durand et al. (1983) in vitro with " batch " incubations of P-deficient sheep rumen contents. However, in vivo these authors did not observe significant differences in microbial yield between P-supplemented and P-depleted sheep when they were fed 8 times a day. Similarly, P deficiency did not alter microbial yield in the continuous culture system (Komisarczuk, Merry and McAllan, 1987). Therefore, discontinuous supply of substrates, and thus variations in the rhythm of fermentation, could be involved in an eventual uncoupling between the growth and degradative capacities of rumen microbes.

The drastic reduction in ATP concentrations in the P-deficient vessels confirms previous results obtained in the continuous culture system (Komisarczuk, Merry and McAllan, 1987). This effect cannot be due to protozoa, as their number was not significantly reduced by the lack of $P$, nor to a shortage of intracellular inorganic phosphorus in the bacteria. The decrease in ATP concentrations obtained was probably a result of both a reduction in microbial catabolic activity (Komisarczuk et al., 1986) and a reduction in the size of the microbial population. 
Further investigations of $P$ deficiency should be able to explain the mechanisms of ATP synthesis in low-P culture media. The effects of other mineral deficiencies on this nucleotide must also be investigated to determine the significance of ATP measurements as an index of microbial activity.

Repletion of $P$ (period II) in the previously P-deficient vessels (period I) clearly shows that the recovey of microbial activity and growth was nearly total and that $P$ deficiency had no irreversible effects. In addition, the tendency for higher recovery of microbial protein synthesis (SAB) was evident as well as a decrease in $A T P$ concentrations and in the $P / N$ ratio in both $S A B$ and $L A B$. This suggests that there was selection for a population having lower $P$ requirements during the first period of $P$ deficiency. The recovery of the activity in the Rusitec with $P$ repletion, already observed by Durand et al. (1986b), was also obtained in vivo by Breves and Höller (1985) who studied the effects of $P$ deficiency using a depletion-repletion technique. On the contrary, in " batch » culture, the addition of $P$ to an inoculum provided by $P$-deficient animals gave incomplete recovery of the microbial activity compared to inocula provided by animals given a normal $P$ supply. Continuous culture systems such as the Rusitec, allowing long adaptation periods, appear to be much more suitable for studying the effects of minerals on rumen microbiota metabolism than short-term incubations.

In conclusion, although $P$ deficiency seems to affect primary cellulose digestion in the rumen, protein synthesis and ammonia utilization are also both significantly affected. These results confirm the importance of phosphorus for the overall aspects of microbial metabolism.

Reçu en janvier 1987 Accepté en mai 1987

Résumé. Effets de la carence en phosphore sur l'activité microbienne du rumen associée aux phases solide et liquide d'un fermenteur (Rusitec).

Le système Rusitec est utilisé pour étudier les effets de la carence en phosphore (P) sur la protéosynthèse, la composition chimique bactérienne et les teneurs en ATP, dans les phases solide et liquide des fermenteurs. Chaque fermenteur reçoit journellement $16 \mathrm{~g} \mathrm{MS}$ d'un aliment mixte carencé en $P$ et est perfusé en continu par environ 1 I d'une salive artificielle carencée $(0 \mathrm{mg} P)$ ou non $(120 \mathrm{mg} \mathrm{P} / \mathrm{I})$ en phosphore. Deux fermenteurs sont utilisés par traitement et, au cours d'une seconde période expérimentale, la perfusion des salives carencées et supplémentées en $P$ est inversée afin d'étudier les effets de la réplétion et de la déplétion en $P$.

Les résultats de la première période expérimentale montrent que la proportion d'azote bactérien incorporé directement à partir des acides aminés ou des peptides alimentaires est plus importante chez les bactéries associées au solide que chez les bactéries de la phase liquide (46 vs $19 \%$ ). La carence en $P$ augmente cette proportion chez les deux types bactériens. La protéosynthèse associée à la phase solide représente en Rusitec environ $30 \%$ du total et la carence en $P$ conduit à une nette diminution de la synthèse protéique microbienne dans les 2 phases. Le rendement microbien de la protéosynthèse totale chute d'environ 5 points ( $\mathrm{g} \mathrm{N} / \mathrm{kg} \mathrm{MOF}$ ) dans les conditions de carence. Les teneurs en ATP sont très fortement réduites dans les 2 phases du fermenteur au cours de la carence mais aucun effet significatif sur le nombre de protozoaires n'est observé.

La déplétion en $\mathrm{P}$ au cours de la seconde période conduit à des effets comparables à la carence directe de la période $\mathrm{I}$ et la réplétion en $\mathrm{P}$ permet de montrer que les effets de la carence sont presque entièrement réversibles. 


\section{Références}

BARTLETT G. R., 1959. Phosphorus assay in column chromatography. J. biol. Chem., 234, 466-468.

BATES D. B., GILLETT J., BARAO S. A., BERGEN W. G., 1985. The effect of specific growth rate and stage of growth on nucleic acid-protein values of pure cultures and mixed ruminal bacteria. J. anim. Sci., 61, 713-724.

BONILLA S. E., 1976. Phosphorus in the nutrition of sheep: composition of body fluids, microbial fermentation and feed intake. Thesis, California Davis Univ., $176 \mathrm{pp}$.

BREVES G., HÖLLER H., 1985. Effekte einer P-Depletion auf die gastro-intestinalen Stickstoffumsetzungen bei Schafen. Z. Tierphysiol. Tierernährg. Futtermittelkde, 54, 63-64.

BREVES G., HÖLLER H., LESSMANN H. W., 1985. Turnover of microbial nitrogen in the rumen of phosphorus-depleted sheep. Proc. Nutr. Soc., 44, 145A.

CZERKAWSKI J. W., 1976. Chemical composition of microbial matter in the rumen. J. Sci. Food Agric., 27, 621-632.

CZERKAWSKI J. W., 1984. Microbial fermentation in the rumen. Symp. on "Model systems in nutritional research ». Proc. Nutr. Soc., 43, 101-118.

CZERKAWSKI J. W., BRECKENRIDGE G., 1977. Design and development of a long-term rumen simulation technique (Rusitec). Br. J. Nutr., 38, 371-384.

DEMEYER D., VAN NEVEL C., 1986. Influence of substrate and microbial interaction on efficiency of rumen microbial growth. Reprod. Nutr. Dévelop., 26, 161-179.

DURAND M., BERTIER B., HANNEQUART G., GUÉGUEN L., 1982. Influence d'une subcarence en phosphore et $d^{\prime}$ un excès de calcium alimentaire sur la phosphatémie et les teneurs en phosphore et calcium des contenus de rumen de montons. Reprod. Nutr. Dévelop., 22, 865879.

DURAND M., BOXEBELD A., DUMAY C., BEAUMATIN Ph., 1983. Influence of the level of dietary phosphorus on urea utilization by rumen microorganisms in lambs, 263-266. IVth Int. Symp. Protein metabolism and nutrition, Clermont-Ferrand (France) 5-9 sept. 1983, éd. INRA, pub. Il (Les Colloques de I'INRA, $n^{\circ} 16$ ).

DURAND M., HANNEQUART G., BEAUMARTIN Ph., DUMAY C., 1986a. Use of the rumen simulation technique (Rusitec) to study the effect of type of feedstuffs and mineral supply on microbial protein synthesis. Arch. anim. Nutr. Berlin, 36, 2-3.

DURAND M., BEAUMATIN Ph., DUMAY C., MESCHY F., KOMISARCZUK S., 1986b. Influence de l'addition de phosphore sur la digestion d'une paille traitée à l'ammoniac par les microorganisms du rumen en fermenteur semi-continu. Reprod. Nutr. Dévelop., 26, 297-298.

FARRIES F. E., KRASNODEBSKA I., 1972. Untersuchungen über die Verwertung von Harnstoff beim Wiederkaüer. Zum Einfluss unterschiedlicher P-Versorgung auf den N-Stoffwecksel bei ausschliesslicher NPN-Zufuhr. Z. Tierphysiol. Tierernähr. Futtermittelkde, 30, 33-47.

FORREST W. W., 1965. Adenosine triphosphate pool during the growth cycle in Streptococcus faecalis. J. Bacteriol, 90, 1013-1016.

5 PSBERG C. W., LAM K., 1977. Use of adenosine 5 'triphosphate as an indicator of the microbiota biomass in rumen contents. Appl. environ. Microbiol., 33, 528-537.

HÖLLER H., BREVES G., MARTENS H., 1983. Non-protein nitrogen and reduced phosphorus supply to sheep, 81-87. In : Nuclear techniques for assessing and improving ruminants feeds. I.A.E.A. Vienna.

HOOVER W. H., CROOKER B. A., SNIFFEN C. J., 1976. Effects of differential solid-liquid removal rates on protozoa numbers in continuous cultures of rumen contents. J. anim. Sci., 43. 528-534.

KOMISARCZUK S., DURAND N.., HANNEQUART G., 1984. ATP measurement in sheep rumen digesta using dimethyl sulfoxide as an extraction reagent. Reprod. Nutr. Dévelop., 24, 903913.

KOMISARCZUK S., DURAND M., DUMAY C., MOREL M. T., 1986. Use of a semi-continuous culture system (Rusitec) to study the effects of phosphorus deficiency on rumen microbial digestion, 47-53. In : H. C. DUBOURGIER et al., Biology of anaerobic bacteria. Elsevier Sci. Publ. B. V. Amsterdam. 
KOMISARCZUK S., MERRY R. J., MCALLAN A. B., 1987. Effects of different levels of phosphorus on rumen microbial fermentation and synthesis determined using a continuous culture system. Br. J. Nutr., 57, 279-290.

LESSMANN H. W., BREVES G., HÖLLER H., 1985. Effekte einer P-Depletion auf den Nettozuwachs an mikrobiell gebundenen Stickstoff im Pansen von Schafen. Z. Tierphysiol. Tierernährg. Futtermittelkde, 54, 65.

McALLAN A. B., SMITH R. H., 1974. Carbohydrate metabolism in the ruminant. Bacterial carbohydrates formed in the rumen and their contribution to digesta entering the duodenum. $B r . J$. Nutr., 31, 77-88.

McMENIMAN N. P., BEN GHEDALIA D., ELLIOTT R., 1976. Sulphur and cystine incorporation into rumen microbial protein. Br. J. Nutr., 36, 571-574.

MERRY R. J., MCALLAN A. B., 1983. A comparison of the chemical composition of mixed bacteria harvested from the liquid and solid fractions of rumen digesta. Br. J. Nutr., 50, 701709.

MERRY R. J., SMITH R. H., McALLAN A. B., 1987. Studies of rumen function in an in vitro continuous culture system. Arch. Tierernähr. (in press).

MICHEL M. C., 1971. Analyse quantitative de quelques substances azotées et glucidiques en milieu biologique. Thèse Doct. Univ., Clermont-Ferrand, 109 pp.

MILTON J. T. B., TERNOUTH J. H., 1985. Phosphorus metabolism in ruminants. II. Effects of inorganic phosphorus concentration upon food intake and digestibility. Austr. J. agric. Res., 36, 647-654.

NUZBACK D. E., BARTLEY E. E., DENNIS S. M., NAGARAJA T. G., GALITZER S. J., DAYTON A. D., 1983. Relation of rumen ATP concentration to bacterial and protozoal numbers. Appl. environ. Microbiol., 46, 533-538.

OTTENSTEIN D. M., BARTLEY D. A., 1971. Improved gas chromatography separation of free acids $\mathrm{C}_{2}-\mathrm{C}_{5}$ in dilute solution. Analyt. Chem., 43, 952-955.

SALTER D. N., DANESHVAR K., SMITH R. H., 1979. The origin of nitrogen incorporated into compounds in the rumen bacteria of steers given protein and urea-containing diets. Br. J. Nutr., 41, 197-209.

SMITH R. H., 1984. Minerals and rumen function, 79-96. In : Nuclear techniques in tropical animal diseases and nutritional disorders, I.A.E.A., Vienna.

SNEDECOR G. W., COCHRAN W. G., 1972. In : Statistical methods. 6th ed. pp. 91-97. lowa State Univ. Press.

VAN NEVEL C. J., DEMEYER D. I., 1977. Determination of rumen microbial growth in vitro from 32p labelled phosphate incorporation. Br. J. Nutr., 38, 101-114.

WITT K. E., OWENS F. N., 1983. Phosphorus ruminal availability and effects on digestion. $J$. anim. Sci., 56, 930-937. 